\title{
Efektivitas Paenibacillus polymyxa dan Pseudomonas fluorescens dalam Pengendalian Penyakit Haur daun (Helminthosporium turcicum) pada Tanaman Jagung (Zea mays L.)
}

\author{
(The Effectivity of Paenibacillus polymyxa and Pseudomonas fluorescens in Biological Control of \\ Helminthosporium turcicum in Maize (Zea mays L.))
}

\author{
Nurlaela Tuszahrohmi ${ }^{1}$, Ugik Romadi ${ }^{2}$, Irianti Kurniasari ${ }^{2 *}$ \\ ${ }^{1}$ Program Studi Penyuluhan Pertanian Berkelanjutan, Politeknik Pembangunan Pertanian Malang \\ Jl. Dr. Cipto 144 A Lawang-Malang 65200 \\ *Email Korespondensi: kurnia_saree@yahoo.com
}

Diterima 19 Juli 2019/Disetujui 03 September 2019

\begin{abstract}
Leaf blight caused by fungi Helminthosporium turcicum is an important disease in Indonesia because of the loss of up to $50 \%$. The use of chemical fungicides continuously has a negative impact on humans and the environment. One of the save and environmentally friendly controls is biological control based on antagonistic microorganisms. This study aims to determine the effectiveness of the biological agents Paenibacillus polymyxa and Pseudomonas fluorescens in the controlling of leaf blight in maize. Randomized Block Design used in this research consist of five treatments and each treatment consist of five replications. The treatments consist of $P 0=$ control, $P 1=P$.polymyxa $10 \mathrm{ml} \mathrm{L} L^{-1}, P 2=P$.fluorescens $10 \mathrm{ml} L^{-1}, P 3=P$.polymyxa dan P.fluorescens $10 \mathrm{ml} L^{-}$ ${ }^{1}, P 4=$ propineb fungicide $70 \%$. The data were analyzed using analysis of variance, if there were significant followed by Duncan test at $5 \%$ level. The results showed that P.polymyxa effectiv reduce leaf blight in maize by $99.89 \%$, besides that P.polymyxa was able to increase plant height and number of leaves significantly compared to controls.
\end{abstract}

Keywords: leaf blight, Helminthosporium turcicum, Paenibacillus polymyxa, Pseudomonas fluorescens, maize

\section{ABSTRAK}

Penyakit hawar daun yang disebabkan oleh jamur Helminthosporium turcicum termasuk dalam penyakit penting di Indonesia dikarenakan kerugian yang disebabkan mencapai 50\%. Penggunaan fungisida kimia secara terus menerus memiliki dampak negatif bagi manusia dan lingkungan. Salah satu pengendalian yang aman dan ramah lingkungan yaitu pengendalian hayati berbasis mikroorganisme antagonis. Penelitian ini bertujuan untuk mengetahui efektivitas agensia hayati Paenibacillus polymyxa dan Pseudomonas fluorescens dalam pengendalian penyakit hawar daun pada tanaman jagung. Perlakuan disusun dalam Rancangan Acak Kelompok $(R A K)$ terdiri dari lima perlakuan dan masing-masing perlakuan terdiri dari lima ulangan. Perlakuan terdiri atas $P 0=$ kontrol, $P 1=$ Penyemprotan P.polymyxa $10 \mathrm{ml} \mathrm{L} L^{-1}, P 2=$ Penyemprotan Pseudomonas fluorescens $10 \mathrm{ml} L^{-1}$, P3=Penyemprotan P.polymyxa dan P.fluorescens $10 \mathrm{ml} \mathrm{L}$, P4=Penyemprotan fungisida propineb $70 \%$. Data yang diperoleh kemudian dianalisis menggunakan analisis varian, jika terdapat beda nyata maka dilanjutkan dengan uji Duncan taraf 5\%. Hasil penelitian menunjukkan bahwa P.polymyxa mampu efektif menekan penyakit hawar daun jagung sebesar 99,89\%, selain itu P.polymyxa mampu meningkatkan tinggi tanaman dan jumlah daun yang signifikan dibandingkan dengan kontrol.

Kata kunci: hawar daun, Helminthosporium turcicum, Paenibacillus polymyxa, Pseudomonas fluorescens, tanaman jagung.

\section{PENDAHULUAN}

Jagung merupakan komoditas pangan yang sedang di kembangkan di Indonesia dalam skala besar. Sebagai sumber pangan, jagung merupakan sumber karbohidrat kedua setelah beras. Peningkatan konsumsi jagung domestik baik oleh industri pangan maupun pakan berdampak terhadap peningkatan permintaan jagung, pada akhirnya produksi jagung juga meningkat. Pemerintah Indonesia menargetkan pada tahun 2017 dapat berswasembada jagung yang diiringi dengan peningkatan ekspor dan penurunan impor jagung. Berdasarkan hasil analisis proyeksi pada tahun 2018 terjadi penurunan surplus dibandingkan dengan tahun 2017. Penurunan surplus ini dikarenakan permintaan kebutuhan jagung lebih tinggi 
dibandingkan produksi jagung nasional. Pada tahun 2021 diproyeksikan lagi akan terjadi surplus jagung sebesar 6.40 juta ton (Pusdatin 2017). Upaya yang dilakukan untuk mendukung hal tersebut adalah perlu adanya peningkatan produktivitas jagung agar kebutuhan jagung dalam negeri dapat terpenuhi.

Salah satu kendala dalam upaya peningkatan produksi jagung yaitu adanya serangan penyakit hawar daun. Penyakit ini termasuk dalam penyakit penting karena kerugian yang disebabkan dapat mencapai 50 (Semangun, 1991). Gejala awal penyakit hawar daun adalah adanya bercak kecil kebasahbasahan, kemudian bercak semakin banyak berwarna hijau kekuningan. Pada tingkat yang parah bercak membesar dan berkembang menjadi nekrotik (Wakman dan Burhanudin, 2004).

Pengendalian yang umum dilakukan oleh petani yaitu pengendalian secara kimia dengan menggunakan fungisida. Penggunaan fungisida kimia yang berlebihan dapat membawa kerugian yang cukup besar. Fungisida berpengaruh terhadap matinya organisme yang bukan sasaran, berkurangnya keanekaragaman hayati dan terganggunya ekosistem sehingga menyebabkan lingkungan tercemar. Salah satu pengendalian yang aman dan ramah lingkungan yaitu pengendalian hayati berbasis mikroorganisme antagonis. Menurut Prasetyo et al, (2017) penggunaan mikroorganisme antagonis sebagai agensia hayati berpotensi tinggi dalam menghambat serangan patogen, dan mampu beradaptasi dan berkolonisasi pada perakaran tanaman. Selain itu juga dapat berfungsi sebagai PGPR (Plant growth promoting rhizobacteria) yang dapat menginduksi ketahanan tanaman inang.

Penelitian ini bertujuan untuk mengetahui efektivitas agensia hayati P.polymyxa dan P.pseudomonas dalam pengendalian penyakit hawar daun pada tanaman jagung.

\section{BAHAN DAN METODE}

Pelaksanaan penelitian pada bulan Maret sampai Mei 2019 di Laboratorium Proteksi Tanaman Balai Besar Penelitian Pertanian (BBPP) Ketindan dan Lahan Politeknik Pembangunan Pertanian Malang. Bahan yang digunakan dalam penelitian ini yaitu benih jagung hibrida Pioneer, isolat Paenibacillus polymyxa dan Pseudomonas fluorescens, fungisida berbahan aktif propineb $70 \%$, alkohol, aquades, pupuk kandang, pupuk urea, daun terserang penyakit hawar daun, kentang, gula, dan air.

Penelitian disusun dalam Rancangan Acak Kelompok (RAK) yang terdiri dari 5 perlakuan dengan masing-masing perlakuan terdiri dari 5 ulangan, sehingga diperoleh 25 satuan percobaan dan masing-masing perlakuan terdiri dari 3 sampel untuk pengamatan tanaman (Tabel. 1).

\section{Perbanyakan Isolat P.paenibacillus dan P.fluorescens}

Isolat murni yang digunakan merupakan koleksi dari UPT Proteksi Balai Besar Pelatihan Pertanian Ketindan. Isolat
P.polymyxa dan P.fluorescens diperbanyak menggunakan ekstrak kentang dan gula, kemudian dilakukan fermentasi menggunakan fermentor sederhana secara aerob pada suhu ruangan.

\section{Penyiapan Lahan}

Lahan yang digunakan dalam penanaman jagung yaitu 15 x 10 meter yang telah dibersihkan dari gulma menggunakan cangkul. Lahan dibuat bedengan sebanyak 25 bedengan dengan ukuran tiap bedengan $2,5 \times 1,5$ meter, tinggi bedengan $50 \mathrm{~cm}$ dan jarak antar bedengan $40 \mathrm{~cm}$.

Jagung ditanam dengan jarak tanam $60 \times 15 \mathrm{~cm}$ setiap 1 lubang tanam 1 biji kemudian ditutup menggunakan pupuk kandang dengan dosis 50gr/lubang tanam.

\section{Inokulasi Jamur Helminthosporium turcicum}

Inokulasi jamur Helminthosporium turcicum pada saat tanaman berumur 14HST dan 21HST dengan cara mencari daun jagung yang terserang penyakit hawar daun, kemudian daun di potong kecil-kecil dan dimasukkan kedalam $1 \mathrm{~L}$ air yang sudah dilarutkan gula sebanyak 10gram. Inokulasi jamur Helminthosporium turcicum dengan cara memberikan $2 \mathrm{ml}$ suspensi ke daun corong yang dilakukan sebelum matahari terbit.

\section{Penyemprotan}

Penyemprotan agensia hayati pada saat tanaman berumur 7HST dan dilakukan setiap interval 7 hari. Penyemprotan dilakukan pada seluruh bagian tanaman dengan konsentrasi $10 \mathrm{ml} \mathrm{L}^{-1}$. Kontrol positif dan negatif di semprot menggunakan air.

Parameter pengamatan

a. Parameter Tinggi Tanaman

Parameter tinggi tanaman diukur mulai 7 HST sampai dengan 56 HST diukur pangkal batang sampai pada titik tumbuh (Sesanti, dkk, 2014).

b. Parameter Jumlah Daun

Parameter jumlah daun diukur mulai 7 HST sampai dengan 56 HST, dengan cara menghitung daun yang telah mekar sempurna.

c. Parameter Intensitas Serangan

Intensitas serangan diamati 3-8 MST dengan cara membandingkan dengan tabel kategori skala kerusakan penyakit hawar daun (Tabel 2). Intensitas serangan dihitung menggunakan rumus menurut Sinaga (2006) seperti dibawah ini:

$$
I S=\frac{\sum(n \times v)}{N \times Z} \times 100 \%
$$

Keterangan :

IS : Intensitas Serangan (\%) 
n : Jumlah bagian tanaman yang terseran (helai)

$\mathrm{V} \quad$ : Nilai skala daun yang terserang

$\mathrm{N} \quad$ : Jumlah daun yang diamati

$\mathrm{Z} \quad$ : Skala tertinggi dari kategori skala serangan

\section{Analisis Data}

Data Pengamatan dianalisis menggunakan Analisis of Varians (ANOVA) dengan taraf nyata 5\%, bila terdapat perbedaan yang nyata maka dilakukan uji lanjut menggunakan Uji Duncan dengan taraf 5\%.

\section{HASIL DAN PEMBAHASAN}

\section{Parameter Tinggi Tanaman}

Hasil pengamatan terhadap semua perlakuan pada minggu ke 1 sampai minggu ke 8 MST diperoleh bahwa perlakuan agensia Paenibacillus polymyxa memberikan pengaruh yang berbeda nyata terhadap peningkatan tinggi tanaman dibandingkan dengan perlakuan yang lain (dapat dilihat pada tabel 3).

Berdasarkan Tabel 3. diperoleh bahwa penggunaan agensia hayati P.polymyxa dan P.fluorescens pada pengamatan minggu ke-1 memberikan pengaruh tidak berbeda nyata terhadap tinggi tanaman. Pengamatan minggu ke-2 sampai minggu ke-8 memberikan pengaruh yang beda nyata pada setiap perlakuan. Rerata tertinggi terdapat pada perlakuan (P1) dan rerata terendah terdapat pada perlakuan (P0). Berdasarkan hasil Uji Duncan diperoleh bahwa penggunaan P.polymyxa,
P.fluorescens, kombinasi, fungisida berbahan aktif propineb $70 \%$ tidak memberikan pengaruh yang beda nyata pada 7 HST, namun berpengaruh nyata pada 14-56 HST.

Pertambahan tinggi tanaman jagung menunjukkan bahwa perlakuan (P1) dapat meningkatkan pertumbuhan tanaman dibandingkan dengan perlakuan yang lain. Hal ini disebabkan P.polymyxa dapat memfiksasi nitrogen dalam tanah. Unsur hara $\mathrm{N}$ berguna untuk menambah tinggi tanaman dan memacu pertunasan (Jumin, 2010). Selain itu berdasarkan hasil penelitian Siregar dkk (2007), bahwa aplikasi P.polymyxa dapat mendukung pertumbuhan tanaman karena bakteri P.polymyxa dapat memproduksi hormon pemacu pertumbuhan tanaman (IAA), auksin dan sitokinin. Menurut Sivasakthi, dkk (2015) juga mengemukakan bahwa bentuk aktif dari IAA yaitu auksin dan sitokinin yang berfungsi dalam peningkatan pertumbuhan tanaman melalui penyerapan unsur $\mathrm{N}, \mathrm{P}, \mathrm{K}, \mathrm{Ca}$ dan $\mathrm{Mg}$.

Bakteri P.polymyxa bukan hanya antagonis terhadap patogen tetapi juga merupakan bakteri yang berfungsi sebagai PGPR (plant growth promoting rhizobacteria) yang dapat memproduksi hormon pertumbuhan yang bertanggung jawab dalam peningkatan tinggi tanaman jagung (Noumavo, dkk, 2013).

\section{Parameter Jumlah Daun}

Hasil pengamatan menunjukkan bahwa agensia hayati dengan berbagai perlakuan memberikan pengaruh berbeda nyata terhadap jumlah daun. Hasil rerata jumlah daun pada berbagai pengamatan dan perlakuan dapat dilihat pada Tabel 4 . dibawah ini :

Tabel 1. Rancangan Perlakuan

\begin{tabular}{cl}
\hline Kode & \multicolumn{1}{c}{ Keterangan } \\
\hline P0 & 0 (Kontrol tanpa perlakuan) \\
P1 & Penyemprotan Paenibacillus polymyxa $10 \mathrm{ml} / \mathrm{L}$ \\
P2 & Penyemprotan Pseudomonas fluorescens $10 \mathrm{ml} / \mathrm{L}$ \\
P3 & Penyemprotan Pseudomonas fluorescens dan Paenibacillus polymyxa $10 \mathrm{ml} / \mathrm{L}$ \\
P4 & Penyemprotan dengan fungisida berbahan aktif propineb $70 \%$ \\
\hline
\end{tabular}

Tabel 2. Kategori Skala Kerusakan Penyakit Hawar Daun

\begin{tabular}{lc}
\hline \multicolumn{1}{c}{ Intensitas serangan } & Kategori \\
\hline Tidak ada serangan & 0 \\
Kerusakan ringan 1-10\% per tanaman & 1 \\
Kerusakan sedang 10-25\% per tanaman & 2 \\
Kerusakan agak berat 25-50\% per tanaman & 3 \\
Kerusakan berat 50-75\% per tanaman & 4 \\
Kerusakan sangat berat 75-100\% per tanaman & 5 \\
\hline
\end{tabular}

Sumber: Ditjen Tanaman Pangan dan Hortikultura (1996) 
Tabel 3. Rerata tinggi tanaman jagung pada berbagai perlakuan dan pengamatan

Perlakuan

P0
P1
P2
P3
P4

Tinggi Tanaman $(\mathrm{cm})$ pada pengamatan minggu ke

\begin{tabular}{cccccccc}
\hline 1 & 2 & 3 & 4 & 5 & 6 & 7 & 8 \\
\hline $9.47^{\mathrm{a}}$ & $18.69^{\mathrm{a}}$ & $34.53^{\mathrm{a}}$ & $46.09^{\mathrm{a}}$ & $64.60^{\mathrm{a}}$ & $145.22^{\mathrm{a}}$ & $189.44^{\mathrm{a}}$ & $231.89^{\mathrm{a}}$ \\
$9.00^{\mathrm{a}}$ & $23.08^{\mathrm{c}}$ & $39.47^{\mathrm{c}}$ & $51.57^{\mathrm{d}}$ & $77.97^{\mathrm{c}}$ & $174.56^{\mathrm{d}}$ & $226^{\mathrm{d}}$ & $272.33^{\mathrm{e}}$ \\
$9.42^{\mathrm{a}}$ & $22.05^{\mathrm{bc}}$ & $37.87^{\mathrm{bc}}$ & $49.11^{\mathrm{bc}}$ & $72.67^{\mathrm{b}}$ & $156.78^{\mathrm{b}}$ & $201^{\mathrm{b}}$ & $251.44^{\mathrm{cd}}$ \\
$9.27^{\mathrm{a}}$ & $21.52^{\mathrm{b}}$ & $37.33^{\mathrm{b}}$ & $50.19^{\mathrm{cd}}$ & $72.33^{\mathrm{b}}$ & $162.83^{\mathrm{c}}$ & $216.89^{\mathrm{c}}$ & $257.67^{\mathrm{d}}$ \\
$8.72^{\mathrm{a}}$ & $21.19^{\mathrm{b}}$ & $35.17^{\mathrm{a}}$ & $47.97^{\mathrm{b}}$ & $67.47^{\mathrm{a}}$ & $148^{\mathrm{a}}$ & $199.67^{\mathrm{b}}$ & $241.44^{\mathrm{bc}}$ \\
\hline
\end{tabular}

Keterangan: Angka yang diikuti huruf yang sama menunjukkan tidak berbeda nyata pada uji Duncan taraf $5 \%$

Tabel 4. Rerata Jumlah Daun berbagai perlakuan dan pengamatan

\begin{tabular}{cccccccccc}
\hline \multirow{2}{*}{ Perlakuan } & \multicolumn{7}{c}{ Jumlah Daun (Helai) pada pengamatan minggu ke } \\
\cline { 2 - 9 } & 1 & 2 & 3 & 4 & 5 & 6 & 7 & 8 \\
\hline P0 & $3.67^{\mathrm{a}}$ & $7.22^{\mathrm{a}}$ & $10.67^{\mathrm{a}}$ & $12.67^{\mathrm{a}}$ & $15.67^{\mathrm{a}}$ & $18^{\mathrm{a}}$ & $20.44^{\mathrm{a}}$ & $22.11^{\mathrm{a}}$ \\
P1 & $3.89^{\mathrm{ab}}$ & $8.11^{\mathrm{d}}$ & $11.44^{\mathrm{c}}$ & $14.33^{\mathrm{c}}$ & $17.44^{\mathrm{b}}$ & $19.89^{\mathrm{c}}$ & $22.22^{\mathrm{c}}$ & $26.22^{\mathrm{d}}$ \\
P2 & $4.22^{\mathrm{b}}$ & $7.33^{\mathrm{ab}}$ & $11.22^{\mathrm{b}}$ & $13.56^{\mathrm{b}}$ & $15.89^{\mathrm{a}}$ & $18.67^{\mathrm{a}}$ & $21.22^{\mathrm{b}}$ & $24.44^{\mathrm{c}}$ \\
P3 & $4.11^{\mathrm{ab}}$ & $7.67^{\mathrm{bc}}$ & $11.33^{\mathrm{c}}$ & $13.78^{\mathrm{b}}$ & $16.22^{\mathrm{a}}$ & $18.78^{\mathrm{b}}$ & $22.44^{\mathrm{c}}$ & $24^{\mathrm{bc}}$ & $23.33^{\mathrm{b}}$ \\
P4 & $3.89^{\mathrm{ab}}$ & $7.67^{\mathrm{c}}$ & $11^{\mathrm{b}}$ & $12.89^{\mathrm{a}}$ & $15.56^{\mathrm{a}}$ & $18.44^{\mathrm{a}}$ & $20.89^{\mathrm{ab}}$ & 23 \\
\hline
\end{tabular}

Keterangan: Angka yang diikuti huruf yang sama menunjukkan tidak berbeda nyata pada uji Duncan taraf $5 \%$

Tabel 5. Perhitungan Intensitas Serangan hawar daun jagung pada berbagai perlakuan dan pengamatan

\begin{tabular}{ccccccc}
\hline Perlakuan & \multicolumn{7}{c}{ Intensitas Serangan (\%) pada pengamatan minggu ke } \\
\cline { 2 - 7 } & 3 MST & 4 MST & 5 MST & 6 MST & 7 MST & 8 MST \\
\hline P0 & $0.1^{\mathrm{b}}$ & $0.14^{\mathrm{b}}$ & $0.19^{\mathrm{c}}$ & $0.26^{\mathrm{c}}$ & $0.19^{\mathrm{c}}$ & $0.25^{\mathrm{b}}$ \\
P1 & $0.04^{\mathrm{a}}$ & $0.04^{\mathrm{a}}$ & $0.05^{\mathrm{a}}$ & $0.07^{\mathrm{a}}$ & $0.11^{\mathrm{a}}$ & $0.11^{\mathrm{a}}$ \\
P2 & $0.06^{\mathrm{a}}$ & $0.05^{\mathrm{a}}$ & $0.09^{\mathrm{a}}$ & $0.11^{\mathrm{a}}$ & $0.14^{\mathrm{b}}$ & $0.12^{\mathrm{a}}$ \\
P3 & $0.05^{\mathrm{a}}$ & $0.05^{\mathrm{a}}$ & $0.07^{\mathrm{a}}$ & $0.09^{\mathrm{a}}$ & $0.12^{\mathrm{a}}$ & $0.12^{\mathrm{a}}$ \\
P4 & $0.07^{\mathrm{a}}$ & $0.06^{\mathrm{a}}$ & $0.13^{\mathrm{b}}$ & $0.18^{\mathrm{b}}$ & $0.16^{\mathrm{b}}$ & $0.18^{\mathrm{a}}$ \\
\hline
\end{tabular}

Keterangan: Angka yang diikuti huruf yang sama menunjukkan tidak berbeda nyata pada uji Duncan taraf 5\%
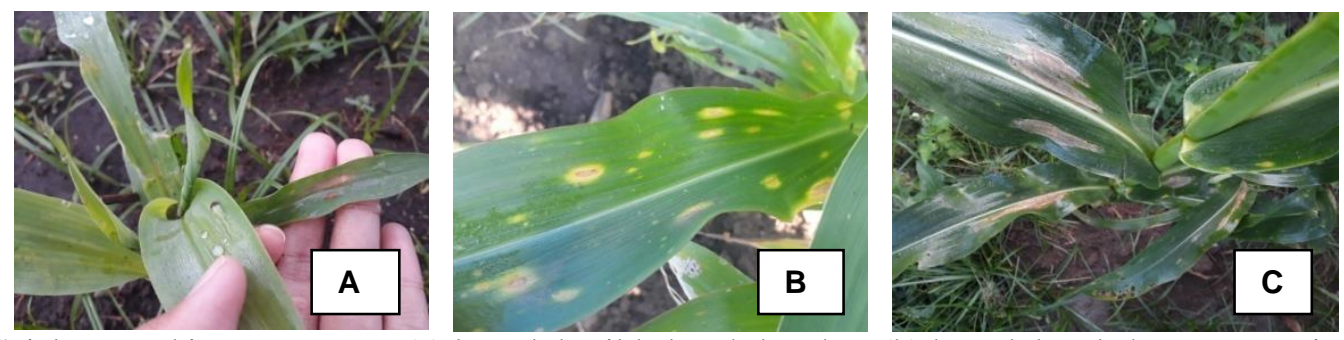

Gambar 1. Gejala Penyakit Hawar Daun (a) bercak kecil kebasah-basahan (b) bercak berubah warna menjadi kuning kecoklatan (c) berkembang membentuk kumparan nekrotik.

Hasil uji Duncan taraf 5\% terhadap rerata jumlah daun menunjukkan bahwa perlakuan (P1) memberikan pengaruh yang berbeda nyata (tabel 4.). Pada pengamatan jumlah daun terlihat bahwa rerata jumlah daun paling banyak diperoleh dari perlakuan (P1) yakni 26.22 helai diikuti perlakuan (P2) 24.44 helai, perlakuan (P3) 24 helai, perlakuan (P4) 23.33 helai dan yang terendah pada perlakuan (P0) dengan nilai 22.11 helai.

Perlakuan dengan jumlah daun tertinggi adalah perlakuan (P1) hal ini disebabkan P.polymyxa dapat berperan sebagai PGPR yang mampu menghasilkan hormon auksin untuk pertumbuhan daun, dimana daun merupakan organ vegetatif pada tanaman yang penting untuk berlangsungnya fotosintetis.

Rerata jumlah daun pada perlakuan (P1) menunjukkan adanya hubungan antara peningkatan tinggi tanaman dengan jumlah daun. Hal ini sesuai dengan pendapat Wahyuti (2012) bahwa tinggi tanaman merupakan faktor penting yang mempengaruhi tingkat kepadatan daun dan kemampuan fotosintesis untuk menghasilkan asimilat. 


\section{Parameter Intensitas Serangan}

Intensitas serangan diamati dari mulai minggu ke 3 sampai dengan minggu ke 8 HST yang dapat dilihat pada tabel 5 .

Gejala awal penyakit hawar daun timbul 3HSI (hari setelah inokulasi) dapat dilihat pada Gambar 1. Pengamatan intensitas serangan dilakukan mulai minggu ke-3 sampai dengan minggu ke-8 yang menunjukkan bahwa perlakuan P.polymyxa mampu mengurangi instensitas serangan penyakit jagung dibandingkan dengan kontrol (P0). Perkembangan penyakit hawar daun jagung pada masing-masing perlakuan P.polmyxa, P.fluorescens, kombinasi dan fungisida berbahan aktif propineb menunjukkan peningkatan setiap minggunya.

Hasil perhitungan menunjukkan adanya beda nyata pada tiap minggu melalui penyemprotan agensia hayati dengan interval waktu satu minggu sekali yang menunjukkan bahwa perlakuan penggunaan agensia hayati dapat menekan intensitas serangan penyakit hawar daun pada tanaman jagung. Tanaman jagung tanpa perlakuan atau kontrol (P0) lebih rentan terkena serangan penyakit hawar daun dengan intensitas serangan paling tinggi. Proses perkembangan patogen akan berlangsung lebih baik pada tanaman jagung yang rentan. Hal ini mengindikasikan bahwa perlakuan penggunaan agensia hayati P.polymyxa mampu menginduksi ketahanan jagung sehingga menghambat patogen dalam menginfeksi tanaman jagung. Menurut Raza, dkk (2008) P.polymyxa menghasilkan antibiotik polymyxin dan fusaricidin yang merupakan antibiotik yang aktif terhadap bakteri gram positif, bakteri gram negatif dan jamur. P.polymyxa dapat menekan intensitas serangan penyakit hawar daun sebesar 99,89\% dibandingkan dengan kontrol.

\section{KESIMPULAN}

Agensia hayati yang paling efektif dalam pengendalian penyakit hawar daun adalah Paenibacillus polymyxa. P.polymyxa mampu menekan penyakit hawar daun sebesar 99,89\% dibandingkan dengan kontrol. Aplikasi P.polymyxa bukan hanya mampu menekan intensitas serangan penyakit hawar daun tapi juga dapat meningkatkan tinggi tanaman dan jumlah daun tanaman jagung.

\section{DAFTAR PUSTAKA}

Direktorat Jenderal Tanaman Pangan dan Hortikultura. 1996. Pedoman Pengamatan dan Pelaporan Perlindungan Tanaman Pangan dan Hortikultura. Jakarta: Direktorat Bina Perlindungan Tanaman Proyek Pengendalian Hama Terpadu

Jumin, H. B. 2010. Dasar-Dasar Agronomi. Jakarta: Rajawali Pers.

Noumavo PA, Kochoni E, Didagbé YO, Adjanohoun A,
Allagbé M, Sikirou R, Gachomo EW, Kotchoni SO dan Baba-Moussa L. 2013. Effect of different plant growth promoting rhizobacteria on maize seed germination and seedling development. American Journal of Plant Sciences, 4(5): 1013-1021.

Prasetyo, G., Suskandini., Ivayani., dan Hasriadi Mat Akin. 2017. Efektivitas Pseudomonas fluorescens dan Paenibacillus polymyxa terhadap Keparahan Penyakit Karat dan Hawar Daun Jagung Manis (Zea mays saccharata). Jurnal Agrotek Tropika Unila. Vol. 5, No. 2: 102-108

Pusdatin. 2017. Outlook Tanaman Pangan dan Hortikultura 2017. Jakarta: Kementerian Pertanian.

Raza W., Young dan Shen, Q.R. 2008. Paenibacillus polymyxa: antibiotics hydrolytic enzymes and hazard assessment. Journal of Plant Pathology. 90(3): 419-430

Semangun, H. 1991. Penyakit-penyakit tanaman pangan di Indonesia. Yogyakarta: UGM Press.

Sesanti, R.N., Wentasari, R., Ismad, W., dan Yanti, W.F. 2014. Perbandingan Pertumbuhan dan Produksi Jagung Manis (Zea mays saccharata L) pada Sistem Tanam Satu Baris dan Dua Baris. Jurnal Agrovigor. Vol.7, No.2: 76-83.

Sinaga, P. 2006. Makalah Pasar Modern VS Pasar Tradisional. Kementerian Koperasi dan UKM. Jakarta: Tidak diterbitkan.

Siregar, A. N., Ilyas, S., Fardiaz, D., Murniati, E., dan Wiyono, S. 2007. Penggunaan Agen Biokontrol Bacillus polymyxa danTrichoderma harzianum untuk Meningkatkan Mutu Benih Cabai dan Pengendalian Penyakit Antraknosa. Jurnal Penyuluh Pertanian. 2 (2): 105-114.

Sivasakthi S, Usharani G dan Saranraj P. 2014. Biocontrol potentiality of plant growth promoting bacteria (PGPR)Pseudomonas fluorescens and Bacillus subtilis: A review. African Journal of Agricultural Research, 9(16): 1265-1277.

Wahyuti, T. B. 2012. Hubungan Karakter Morfologi dan Fisiologi dengan Hasil dan Upaya Meningkat Hasil Padi Varietas Unggul. Bogor: Sekolah Pasca Sarjana. IPB.

Wakman, W. dan Burhanudin. 2004. Pengelolaan Penyakit Prapanen Jagung. Maros: Balai Penelitian Tanaman Sereali. 